\title{
Albanian Individual Taxpayers Perceptions and Determinants on Ethical Behavior Regarding Tax Compliance
}

http://doi.org/10.21272/bel.5(1).66-80.2021

Michael J. Salé, ORCID: https://orcid.org/0000-0003-0483-4101

DPS in Computing Studies, Assistant Professor of Management Information Systems, Leo J. Meehan School of Business, Stonehill College, MA, USA

Oltiana Muharremi, ORCID: https://orcid.org/0000-0002-3931-2656

PhD in Finance, Assistant Professor of Accounting, Leo J. Meehan School of Business, Stonehill College, MA, USA

Meleq Hoxhaj, ORCID: https://orcid.org/0000-0001-9437-887X

Master of Science in Economics, Researcher Scholar, Albanian Customs Administration, Albania

\begin{abstract}
Tax evasion and tax avoidance are among the most addressed topics in economic literature in recent years, as one of the most discussed issues in different countries. The research's primary purpose is to present Albanian residents' and taxpayers' perceptions regarding tax evasion, tax avoidance, and tax compliance. The leading indicators used in this report, the attitude towards tax evasion and tax avoidance, rely on individual taxpayers' perceptions and not on factual evidence such as the amount of income hidden from the tax authorities. Several studies have been done in different countries regarding the population's perception regarding factors affecting evasion. In this paper, we investigated the following logical sequence: in the beginning, we provided an overview of the fiscal system and legislation, informal economy, and fiscal evasion in Albania. This analysis data was taken from reports from national and international organizations. After this, we analyzed data obtained from a survey issued to 387 taxpayer individuals in Albania. Our objective was to identify, using empirical analysis, factors that influence an individual's ethical perception of tax avoidance and evasion. The statistical analyses we carried out in the paper were factor analyses and ordinal logistic linear regression analyses using the JMP statistical software. Based on the empirical research, we concluded that government policies positively correlate with taxpayers' behavior regarding tax compliance. Among other determinants influencing tax evasion, we have evaluated that higher tax rates are an essential element. The results of the research can be helpful for governments and other policymakers' institutions.
\end{abstract}

Keywords: Factors, Fiscal Evasion, Reform, Taxpayers, Tax Compliance.

JEL Classification: H21, H24, H26.

Cite as: Salé, M.J., Muharremi, O., Hoxhaj, M. (2021). Albanian Individual Taxpayers Perceptions and Determinants on Ethical Behavior Regarding Tax Compliance. Business Ethics and Leadership, 5(1), 66-80. http://doi.org/10.21272/bel.5(1).66-80.2021.

Received: 10 February 2021

Accepted: 20 March 2021

Published: 30 March 2021

Copyright: (C) 2021 by the author. Licensee Sumy State University, Ukraine. This article is an open access article distributed under the terms and conditions of the Creative Commons Attribution (CC BY) license (https://creativecommons.org/licenses/by/4.0/).

\section{Introduction}

At first, we need to understand that tax evasion is a very complex and dynamic phenomenon. This result is attributed to the fact that the action of the various actors is interacting in the process. On one side, the government acts as the legislator, which sets the tax rate and social welfare laws. The fiscal administration, which takes care of the application aspects, promotes, and enforces the tax compliance rules. On the other side, there are the citizens, who, on the one hand, modify their behavior in response to the legislation and the practical ways in which it is implemented, and on the other, act as voters, determining the legislation in force and affecting the administration's practices. In Albania, as in other countries, tax avoidance and tax evasion have a considerable effect on the loss of budget income that may have been intended to enhance public services for a more significant benefit. Feige (1990) stated that the scale and rise of unreported profits and the implicit tax difference influence the size of budget deficits, government debt, and tax reform policies. Besides, this 
could have consequences for economic planning as the official statistics would be inaccurate. There are also consequences for regional comparisons, requirements, and obligations. Albania, during the years 1945-1990, the period of dictatorship, was a centralized economy where Albanian finances were focused on planning and centralization and collective work. One of the characteristics of the communist system was the disappearance of private property. Albanians were convinced that: Albania was the only country that did not pay taxes and fees, but the "Labor party" provided every service. Nevertheless, the truth was different, and this was just official propaganda. Simultaneously, as in any other country, the inhabitants paid taxes and duties. They were included in the predetermined and controlled prices of goods, services, and other commodities provided by the state sectors and the economy's cooperative sectors for rural areas. The consequences of this propaganda continued in the years of transition, making it difficult for many citizens to accept and pay tax obligations.

Albania paved the way for democratic developments and a market economy in the early 1990s. These changes brought the beginning of the development of a new tax system. Just like in other former communist countries of Eastern and Central Europe, the country has a relatively new tax system, creating and implementing the legal basis from the beginning. In formulating and implementing fiscal reforms, the country has had support from international institutions such as the IMF and the World Bank. The legislation writing was based on the developed western countries' experience. In these three decades, there have been frequent changes regarding tax policies and rules for each administration. Each country has characteristics and features of different economic and social structures. However, some of Albania's aspects are a deficient culture of paying taxes, a high level of informality in the economy, unclear law on property, and the vital role of agriculture in GDP structure and employment.

There have been discrepancies between tax policy and country characteristics. There have also been significant shortcomings in the administration of tax collection over the years by tax authorities, ineffective control policies, low impunity for non-payers, all creating narrow tax bases and distorting complex and challenging tax systems to be understood and administered. Frequent changes in tax legislation and variations in the tax base have negatively affected the distortion of business investment decisions and foreign investment attraction, which results in lower figures than the region's countries, and the problematic implementation of business operations. Employees are one of the main factors impacting the informal economy. Albanian Center for Economic Research (ACER) \& Southeast Europe Leadership for Development and Integrity ${ }^{l}$ report that informal work is expressed in different patterns in Albania: $39.75 \%$ of workers have declared that they do not have a signed contract. In comparison, $30.29 \%$ of employees have claimed that they do not account for social and health care. Most of these workers without a formal contract are employed in the private sector. Employers do not pay taxes on wages, retirement, and medical insurance, and workers, on the other hand, receive more income even though they are short-term bonuses.

Among Albania's last three decades' most critical problem is tax collecting institutions' inability to collect all tax liabilities from individuals and businesses. One of the critical reasons for the tax disparity is taxpayers' and prospective taxpayers' inability to comply with tax laws. One of the other reasons is the informal economy level, which refers to international organizations' reports. The World Bank Group $(2013)^{2}$, through an empirical study, showed that $37.3 \%$ of businesses believed that the court system is fair, impartial, and uncorrupted (primarily small and medium-sized businesses). Among other significant problems, they evaluated tax administration, tax collection, and corruption by public officials. Another metric used was the number of companies that began to operate without formal registration. The amount was 100 percent of all start-up firms, which directly approximates the prevalence of informality in the private economy.

For the years 1996-2012, based on the method used, the lowest value was $13.6 \%$ of GDP (using simple currency ratio) and the highest value 38\% of GDP (using the electrical energy consumption method). Moreover, Albanian government assessments over the years have shown that the level of informality in the economy is very high. According to the European Monetary Fund data, Albania's informal economy had a minimum level of $25.52 \%$ in 2012 and the maximum level of $43.1 \%$ in 1990 . Over the years, various governments have undertaken policies to combat these phenomena. For the government to undertake as fruitful procedures as possible so that taxpayers' behavior can be changed by making them more accountable, it is also essential to understand and identify their perception. Some of the worth mentioning elements in Albania's high informality are undeclared work, reporting annual turnover, and lower incomes than in reality. One of the most used practices in Albania is cash payment or clearing (exchange agreement). These have made it difficult for governments to control all tax transactions. The paper is organized as follows. After the introduction, the

${ }^{1}$ https://acer.org.al/

${ }^{2}$ http://documents1.worldbank.org/curated/en/337391468003295834/pdf/922900WP0Box380PUBLIC00Albania02013.pdf 
second section shows the literature review. The third section addresses the methodology and empirical analysis and testing of the hypothesis - the fourth section presents conclusions and discussion and some limitations in the research and future work projects.

\section{Literature Review}

Fiscal evasion or concealment of income for non-payment of tax liabilities, increased declaration of expenditures, is an old story in the world, which was born in parallel and at the same time with the state itself. Financial deviations are actions that intentionally misinterpret the performance of a company's financial report or statement, as well as its economic terms. They range from the simplest, such as changes in accounting provisions, to the most severe, fraudulent recognition or misstatement of false income. Legal tax evasion can occur because of legal ambiguities. Tax avoidance is tax mitigation, tax planning, or legal tax minimization by creating financial means and anything else legally permissible. Avoiding taxes further lower budget revenues and puts into disrepute the tax scheme. Hence, governments must either stop tax evasion or hold tax avoidance within limits. Regardless of the ways, all cases of tax evasion are contrary to the national interest. Undoubtedly, the reduction of financial resources from non-payment of tax obligations affects public investments and expenditures and increases public debt. As one of the tax evasion elements, it is worth mentioning that unfair competition is a pervasive phenomenon in Albania's transitional years.

One of the crucial questions regarding the tax evasion phenomenon is why people cheat with taxes and fees?

2.1 Theoretical Framework. The phenomenon of tax avoidance and tax evasion has a shared objective: to pay fewer taxes and 'circumvent' tax legislation. Often the two words are readily misunderstood, but there is a significant distinction between the criminal and administrative aspects. In general, while the ultimate objective in both circumstances is not to satisfy one's fiscal obligations based on one's economic availability, tax avoidance consists of transactions without economic substance that, while respecting the law, ensure indirect tax advantages favors of taxpayers. Tax avoidance is intermediate between tax evasion (open breach of the normative requirements of tax law, failure to disclose and/or falsification of data) and legal savings (tax preparation as a lawful exercise of the independence and contractual autonomy of the parties) (Tanto, 2021). Fiscal evasion is a very complex phenomenon. Different economic, psychological, and sociological theories give various reasons:

2.1.1 Economic Theories. Traditional and economic theories base their analysis on the premise that the human being has a rational behavior in estimating the costs and advantages of choosing an action. The behavioral model of homo economicus does not clearly distinguish the two phenomena in terms of the degree of legality but is based on the concept of risk. Any individual is likely to become evasive if they think that marginal benefits will be higher than marginal costs, depending on the probability of being detected. The task arises for states to implement adequate controls that would prevent the actions of evaders. Models have been developed that consider the benefit of non-payment, the structure of penalties, and the probability of tax authorities' detection.

Torgler and Schaltegger (2006), Slemrod (2007) included individual choices (choices on the labor market, sectoral options, elusive decisions), as well as alternative sanctions, the introduction of alternative penalties, taxes, and withholding taxes as essential elements that affect tax evasion. They also consider incorporating the ambiguity and uncertainty about irrelevant budgetary criteria, recognizing the usefulness of providing public services, giving rewards positive to individuals for honesty, and selection rules that allow systematic checks. The tax administration decides whom to monitor and control based on tax return records. Some authors think that it is precisely the high tax rates that affect the decline in tax compliance. Fisman and Wei (2001) acknowledge that a higher tax rate encourages evasion. After studying the phenomena in Albania, Gashi and Kukaj (2016) concluded that tax rates are crucial when planning the country's fiscal policy to promote tax avoidance and deter customs duties. Any other research, on the other hand, looks at the case with skepticism. Adebisi and Gbegi (2013) have shown a negative correlation between tax rates, tax avoidance, and tax evasion. It is essential for every state that citizens cooperate with state norms and institutions. It is fundamental that they have the will and desire to pay taxes and why this depends directly on several factors. Economists focus on external factors such as fiscal pressure, income levels, the efficiency of controls exercised by tax authorities, fees, and penalties in non-payment, but studies also focus on social and psychological factors.

2.1.2 Psychological Theories. Psychological theories consider the economic explanation very simple. Like economists, psychologists explain human behavior as a function of individual variables, but much more complex and complicated than those used by economists. An essential variable of these is tax evasion's moral acceptability, while human beings are moral beings. Via observational or field research on tax behavior, 
psychologists have measured and examined in-depth psychological variables such as social perceptions and government attitudes in recent years. Moreover, economic variables depend on the perception and attitude of the individual, who belong to psychology. Camerer et al. (2004) show that economic behavior is highly dependent on psychological, institutional, cultural, and even biological factors. Albania is one of the developing countries in the Mediterranean. There is no lack of evidence for the hypothesis that there is a "Mediterranean culture" of evasion. It is known that the Romans have hidden their jewels to avoid luxury taxes and that Greece, Italy, Spain, and Portugal are among the Mediterranean countries with the highest rate of evasion or underground economic rates in the Western world to date (Santoro, 2010). Bosco and Mittone (1997) follow an altruistic perspective and emphasize that taxpayers are concerned about their well-being and social well-being. Their option of escape is limited by the reality such that their escape reduces the amount of money available for social well-being.

Andrighetto et al. (2016) conducted a cross-analysis study based on national stereotypes between Sweden and Italy, where they forecast a higher degree of integrity in Sweden than in Italy. The results indicate that where both countries face a tax compliance scenario consisting of a transparent tax system, an efficient allocation regime, and simple audit rules and penalties, the average credibility level is relatively high. The viability of an agreement between the taxpayer and the government relies on the government taxpayer's view. Kogler et al. (2013) and Turner (2005) have shown that the degree of voluntary enforcement is more affected by taxpayers' confidence in the government, particularly the tax system. Psychological research indicates that internal variables are of equal significance to economic elements: the perception of tax laws by taxpayers, their attitudes to government and taxes, personal expectations, social norms, and openness, as well as motivational enforcement tendencies, are psychological determinants that shape behavior towards taxes (Hofmann et al., 2008; Kirchler, 2007). Based on the findings, Kogler and Kirchler (2019) analyze the importance of taxpayers' social representations and behaviors towards taxes and discuss independent research on tax actions from the psychological literature. All these findings show a significant but moderate impact of social representations and attitudes on tax conduct.

2.1.3 Sociological Theories. Sociological theories say that the cause must be sought in the structure of the social system. The taxpayer lives and works in society, and their behavior is formed, not only by laws and administrative rules but also by their social environment. They are rewarded and punished not only by the law but also by society for their actions. Social norms and their persistence can, however, modify personal norms in the event of a conflict. A person who is not very honest can become more honest by internalizing the social norm over time. However, it is necessary to consider that a government that tolerates tax evasion can lead a person to think that the social norm is represented by the possibility of escaping so that his norm over time could be induced to change in favor of tax dishonesty. Many norms and expectations will affect individuals' behavior, especially national norms and traditions, family norms, and workplace norms and practices. Onu and Oats (2016) show that people's tax enforcement attitudes and actions shift after interacting with other taxpayers about taxes. One of the critical predictors of tax fairness is known to be social norms. They are evaluated as independent variables and views on government and governance, law enforcement, and the tax system's justice. According to them, evasion is a social phenomenon. When there is a lack of taxpayer awareness and the tax system and its complexity, it affects tax evasion. Personal norms include factors related to personality, moral values, beliefs. Wenzel (2004) concluded an empirical study in Australia. He defined three types of standards, personal norms, social norms, and norms relating to the expanded society, based on the theory of selfcategorization. When taxpayers identify with the culture to which expectations are applied, social norms should elicit concomitant actions, internalize social norms, and function accordingly.

The psychological position that audit likelihood has as an external motivator with an effect on tax enforcement is emphasized by Fischer et al. (1992). People think that the probability of detecting tax evasion scams will increase every time controls are exercised over the company, and why this is not entirely true. Salzman et al. (1998) state that taxpayers have different and contradictory behaviors regarding audit probability. It often happens that they overestimate it, and there are other cases when after auditing a company and not detecting fraud, the tendency is reduced. Penalties are also substantial. More considerable fines are more effective intimidation than more frequent audits. Through empirical research, Kleven et al. (2011) focused on 40,000 individual income tax filers in 2011 in Denmark, half of them randomly audited and half of them not. The results may be explained by broadening the traditional (rational) tax avoidance model to allow a crucial distinction between self-reported income and reported income from third parties. Alm and Torgler (2011), Alm et al. (2016) conducted studies and evaluated the existence of a positive relationship between tax evasion and corruption. Sanyal et al. (2000) found that tax revenue falls with the rate of income tax in the presence of dishonest and unethical tax authorities in countries where the degree of corruption is high. Payne and Saunoris (2020) determined that 
corruption has a more significant effect as tax avoidance is a ubiquitous and widespread element. They assessed the firm-level features of a heterogeneous effect on the conditional distribution of tax evasion. Regarding the policy ramifications, the findings showed that measures aimed at lowering tax burdens and controlling corruption would be more successful while tax evasion is prevalent. A positive and vital relationship between the level of education, tax awareness, and tax enforcement has been developed by Kasipillari et al. (2013). Abdu et al. 2021 have demonstrated that corruption promotes a system of tax non-compliance among subSaharan African companies because defaulting firms bribe tax officials to stop paying taxes and to be punished for that. Results also indicated that the perceived confidence of tax authorities is vitally essential in promoting tax compliance among SSA firms. Understanding taxation is one of the first variables to affect tax enforcement. Tax systems are inherently complex, and empirical evidence suggests a low level of knowledge (McKerchar, 2001). A lack of comprehension of complicated tax laws confuses, leading to mistrust and negative tax enforcement attitudes. Based on an observational analysis in Italy, Chiarini et al. (2013) examined the high degree of tax rates among taxpayers' principal tax evasion determinants. Misuse of administrative tax proceeds and the supposed low chance of detection are among the key factors affecting tax compliance.

Chen et al. (2019) have shown that the tax burden, the size of the tax system, the strength of regulation, unemployment, agricultural jobs, and economic transparency have had significant positive effects on China's shadow economy. In contrast, the ratio of direct taxes to indirect taxes, fiscal stability, and income levels have had significant adverse effects on China's shadow economy. The taxpayer's revenue sources are one of the most significant considerations in deciding whether to evade taxation. There is almost no room for tax avoidance for taxpayers whose compensation is primarily derived from employment or benefits since withholding tax is levied on employers by law. In 2001, just one percent of revenue from salaries and wages was not reported in the United States, according to Slemrod (2007). D'Attoma et al. (2017) have found that even when institutional changes and reforms have successfully targeted and significantly narrowed legal and formal gender inequalities, behavioral disparities between males and females persist. A research was conducted in Kosovo by Mamuti and Mc Gee in 2016. They found that tax evasion is considered a less severe crime than other crimes. Tax evasion is not a matter of state financial policies, rather than values and social morality.

Muharremi et al. (2014) showed that the heavy tax burden is considered one of Albania's most significant tax evasion elements. To determine Albania's tax evasion determinants, Andoni et al. (2017) performed an empirical study. Personal income and benefit tax rates, market situation, fiscal legislation, and tax administration capabilities are the five critical determinants that positively affect Albania's tax evasion. The company's turnout has a negative impact. After conducting an empirical study in Elbasan, Albania, regarding the expectations of taxpayers, Muceku and Balliu (2017), in a study conducted in Albania, concluded that taxpayers have very little faith in the fairness of the current tax system. They also found a strong correlation between education level and the taxpayer's income and their views of tax justice. In their attitudes toward the tax system, these opinions are reflected. Tanto (2021) found that in Albania, the tax disparity exists due to the non-implementation of regulations and the lack of taxpayers' willingness to enforce them, creating a shortfall in the accumulation of tax revenues. They claimed that there is a general anti-avoidance standard in the Albanian tax legislation that needs to be modified to improve the usefulness of this rate as the legal basis for addressing tax avoidance.

2.2 Study Objectives and Hypotheses. This study's primary objective was to determine Albanian taxpayers' perceptions of various aspects concerning taxation. The interviewees are natural persons, residents in urban and rural areas, and Albanian citizens of adult age. All persons involved in the study in one form or another, as employees, consumers, are taxpayers. Another research question relates to the impact of individual factors on tax evasion in Albania. In the group of demographic elements, we have considered: gender, age, university education level, and residence. In the framework of this research question, the following auxiliary hypotheses have been posed:

H1. Unfair competition affects tax evasion. Unfair competition at high levels would encourage tax avoidance and tax evasion.

H2. Government transparency and behaviors regarding the use of taxes and duties affect the tendency for tax evasion, and the more informed individuals are about the use of their taxes and the more they approve of how the government handles taxation, the more ethical they are towards tax avoidance and tax evasion.

H3. Perception of the tax system affects behavior towards tax evasion and tax avoidance. The fairer the tax system, the more ethical the behavior of people will be towards tax avoidance and tax evasion. 
H4. The level of corruption of the tax administration affects the behavior of people towards tax evasion. The more the tax administration deteriorates, the more unethical is the behavior of people against tax avoidance and tax evasion.

\section{Methodology}

This paper used a mixed-methods research design. The qualitative aspect of the research included providing an in-depth overview of theoretical and scientific studies in this research field. The quantitative aspect of the research included obtaining primary data through the distribution and analysis of survey responses. The quantitative analysis in the research is described next. The first phase consisted of presenting a draft survey to a small group of colleagues and experts in taxation and psychology for review. Results from this review indicated the need for rewording several of the questions and correcting various technical errors. In the next phase, we piloted the survey by conducting 30 field interviews. Results from pilot testing led to recommendations for further clarification of various questions. Following the recommendations, the final survey was created and distributed online and through social media platforms and email for data gathering. The final phase consisted of quality control of the completed surveys. The respondent data were then analyzed using the JMP statistical software.

Participants. The survey respondents consisted of Albanian citizens meeting specific requirements and having various characteristics. Data were obtained from 387 individual taxpayers in total. (see Appendix B and C for the characteristics of survey participants and the distribution of these characteristics amongst the respondents, respectively). We collected answers from respondents from February until July 2020.

Material. The survey included six demographic questions and 28 questions pertaining to Albanian tax policy and tax avoidance and evasion ethics. Of the 28 study questions, 23 pertained to Albanian tax policy, and five questions pertained to the respondents' beliefs regarding the ethics of tax avoidance and evasion. These two categories of questions will hereafter be referred to as independent and dependent variables, respectively. Several survey questions are original, and others have been used in prior studies about tax evasion in other countries (McGee, 2014; Tarekegn, 2016). Examples of questions are "The progressive personal income tax system is fair" and "Individuals have information on how the taxes collected by them from the government are used." The non-demographic responses were on a 7-point Likert response scale ranging from $1=$ Strongly Disagree, 2 = Disagree, $3=$ Somewhat disagree, $4=$ Neither agree nor disagree, $5=$ Somewhat agree, $6=$ Agree, 7 $=$ Strongly agree. The questions used for the empirical analyses are provided in Appendix A.

Procedure. We published the final survey using Google Forms on social media (Facebook) and distributed the survey to various respondents via email using disproportionate stratified random sampling to collect data. The individuals selected fulfilled the requirement that we received respondents from different age groups, genders, employment statuses, and education levels. We also requested that respondents ask others to complete the survey, thus utilizing a small amount of snowball sampling.

Data Screening. There were no missing values as all survey questions were required. The generally accepted sample size for factor analysis of 10 times the number of variables was met. Our final sample size was 387.

3.1 Factor Analysis. Initially, the factorability of the 23 independent variables was tested. A simple correlation matrix resulted in a significant correlation of .4 for most variables. Because the survey variables are ordinal, a Spearman rank correlation coefficient and Kendall's $\tau b$ were conducted. Both tests resulted in statistically significant correlation values between each variable and at least one other variable at an alpha-level of .05. Given these results, factor analysis was determined to be suitable for all variables. Because the ability to identify latent constructs of our survey questions was important, factor analysis was chosen as the variable reduction technique. The initial eigenvalues explained $24 \%, 13 \%, 10 \%$, and $6 \%$ of the total variance in the first four factors. The fifth and sixth eigenvalues measured just over 1.0, and all others resulted in eigenvalues under 1.0. Factor counts of three, four, five, and six were reviewed using the oblimin rotation method. The five-factor solution was selected for multiple reasons: 1) it explains approximately $57 \%$ of the variance, 2) a leveling off of the scree plot after five factors, 3) an insufficient number of loadings for the four and six-factor solutions, and 4) difficulty interpreting the identities of the latent constructs in the three-factor solution. Six items were eliminated due to cross-loading of .3 or above. These items were: Item 1, Item 4, Item 19, Item 21 , Item 23, and Item 24. The results from this factor analysis can be seen in Table 1. 
Table 1. Factor Loadings based on a Factor Analysis with Oblimin Rotation for 23 Independent Items from the Survey $(\mathrm{N}=387)$

\begin{tabular}{|c|c|c|c|c|c|}
\hline & Government & $\underset{\text { Rate/System }}{\text { Tax }}$ & $\begin{array}{l}\text { Tax } \\
\text { Legislation/ } \\
\text { Collection }\end{array}$ & $\begin{array}{c}\text { Tax } \\
\text { Use/Enforcement }\end{array}$ & $\begin{array}{l}\text { Perceptions } \\
\text { of Tax } \\
\text { Culture }\end{array}$ \\
\hline $\begin{array}{l}\text { Item 7: The government properly uses the } \\
\text { taxes and fees collected }\end{array}$ & 0.79 & & & & \\
\hline $\begin{array}{l}\text { Item 6: I am confident that the } \\
\text { government is doing a good job in } \\
\text { collecting taxes }\end{array}$ & 0.73 & & & & \\
\hline $\begin{array}{l}\text { Item 8: Individuals have information on } \\
\text { how the taxes collected from them by the } \\
\text { government are used }\end{array}$ & 0.70 & & & & \\
\hline $\begin{array}{l}\text { Item 9: The government is interested in } \\
\text { having the opinion of the taxpayer's } \\
\text { before making legal changes }\end{array}$ & 0.70 & & & & \\
\hline $\begin{array}{l}\text { Item 11: I believe the government is } \\
\text { fighting and punishing people who avoid } \\
\text { taxes and commit tax evasion }\end{array}$ & 0.66 & & & & \\
\hline $\begin{array}{l}\text { Item 4: The tax system of our country is } \\
\text { fair to everyone }\end{array}$ & 0.53 & 0.38 & & & \\
\hline $\begin{array}{l}\text { Item 1: Tax legislation is simple to } \\
\text { understand and apply }\end{array}$ & 0.43 & & 0.31 & & \\
\hline $\begin{array}{l}\text { Item 2: The personal income tax rate is } \\
\text { appropriate }\end{array}$ & & 0.75 & & & \\
\hline $\begin{array}{l}\text { Item 3: The social and health insurance } \\
\text { contribution rate is appropriate }\end{array}$ & & 0.66 & & & \\
\hline $\begin{array}{l}\text { Item 5: The progressive personal income } \\
\text { tax system is fair }\end{array}$ & & 0.58 & & & \\
\hline $\begin{array}{l}\text { Item 28: The lack of proper tax culture } \\
\text { influences tax avoidance and tax evasion }\end{array}$ & & & 0.64 & & \\
\hline $\begin{array}{l}\text { Item 27: Misuse of revenues collected by } \\
\text { the government influence tax avoidance } \\
\text { and tax evasion }\end{array}$ & & & 0.64 & & \\
\hline $\begin{array}{l}\text { Item 23: A lack of transparency } \\
\text { regarding fiscal changes and reforms } \\
\text { encourage tax avoidance and tax evasion }\end{array}$ & & & 0.47 & 0.34 & \\
\hline $\begin{array}{l}\text { Item 21: A high level of corruption from } \\
\text { the tax administration influences tax } \\
\text { avoidance and tax evasion }\end{array}$ & -0.37 & & 0.36 & & \\
\hline $\begin{array}{l}\text { Item 26: Non-severe punitive measures } \\
\text { for violators of the law encourages tax } \\
\text { avoidance and tax evasion }\end{array}$ & & & 0.33 & & \\
\hline $\begin{array}{l}\text { Item 25: Frequent and increasing changes } \\
\text { of the tax base encourage tax avoidance } \\
\text { and tax evasion }\end{array}$ & & & & 0.64 & \\
\hline $\begin{array}{l}\text { Item 20: Continuous changes in tax } \\
\text { legislation and the level of taxes } \\
\text { encourage tax avoidance and tax evasion }\end{array}$ & & & & 0.63 & \\
\hline $\begin{array}{l}\text { Item 22: The ability of tax administration } \\
\text { to control and collect taxes and levies } \\
\text { from individuals and businesses } \\
\text { influence tax compliance }\end{array}$ & & & & 0.42 & \\
\hline $\begin{array}{l}\text { Item 19: The desire to achieve significant } \\
\text { profits in a short time encourage evasion }\end{array}$ & & 0.30 & & 0.37 & \\
\hline $\begin{array}{l}\text { Item 24: Unfair competition between } \\
\text { business influence tax avoidance and tax } \\
\text { evasion }\end{array}$ & -0.35 & & & 0.31 & \\
\hline $\begin{array}{l}\text { Item 13: There is a general culture in } \\
\text { Albania regarding tax avoidance and tax } \\
\text { evasion }\end{array}$ & & & & & 0.50 \\
\hline $\begin{array}{l}\text { Item 12: The consequences of catching } \\
\text { for tax evasion (measures, penalties, } \\
\text { fines) are not very serious }\end{array}$ & & & & & 0.44 \\
\hline $\begin{array}{l}\text { Item 10: The current fiscal system favors } \\
\text { high-income individuals rather than low- } \\
\text { and middle-income individuals }\end{array}$ & & & & & 0.32 \\
\hline
\end{tabular}

Notes: Factor loadings <.30 are suppressed. Items in italics were eliminated due to cross-loading

Source: Authors' elaboration 
Confirmatory factor analysis was performed with the remaining 17 variables, again using the oblimin rotation. The first five factors explained $62 \%$ of the variance. Only one variable (Item 10) in the confirmatory factor analysis exhibited a loading under .30. However, this factor had a loading of over .30 with no cross-loading in the initial analysis. Internal consistency was measured using Cronbach's Alpha. The alphas were moderate to very good except for one factor: .85 Government ( 5 items), .77 for Tax Rate/System ( 3 items), .65 for Tax Legislation/Collection ( 3 items), .73 for Tax Use/Enforcement ( 3 items), and .40 for Perceptions of Tax Culture (3 items). No substantial increases in alpha for any of the scales could have been achieved by eliminating more items. We realized that the questions asked in the Perceptions of Tax Culture factor might not have captured a true evaluation of Albanian tax culture. In the light of this element and the poor reliability of this scale, we eliminated this factor was from further consideration. Composite scores were created for each of the four remaining factors by calculating the mean of each factor's components/primary loadings. The skewness and kurtosis were within the range for assuming a normal distribution, and examination of the histograms suggested that the distributions looked nearly normal (see Table 2 for descriptive statistics for the four factors). Overall, these analyses indicated that four distinct factors were latent in an individual's opinion and perceptions toward the tax system in Albania, and these factors were internally consistent. The new scales were used as predictor variables in our ordinal logistic regression.

Table 2. Descriptive Statistics and Cronbach's $\alpha$ for Four Factors $(\mathrm{N}=387)$

\begin{tabular}{|l|c|c|c|c|c|c|}
\hline & \# of Items & M & SD & Skewness & Kurtosis & Cronbach's $\alpha$ \\
\hline Government & 5 & 2.87 & 1.53 & 0.71 & -0.21 & 0.85 \\
\hline Tax Rate/System & 3 & 4.05 & 1.66 & 0.01 & -0.84 & 0.77 \\
\hline Tax Legislation/Collection & 3 & 4.47 & 1.47 & -0.34 & -0.33 & 0.65 \\
\hline Tax Use/Enforcement & 3 & 4.82 & 1.64 & -0.53 & -0.44 & 0.73 \\
\hline
\end{tabular}

Source: Authors' elaboration

\subsection{Data Analysis \& Discussion}

3.2.1 Ordinal Logistic Regression Analysis. We used ordinal logistic regression analysis to investigate which of the four variables shaped a person's ethical principles surrounding tax evasion and avoidance. These ethical beliefs were obtained through Items $14-18$ on the survey. The predictor variables, derived through the factor analysis, were tested a priori to verify there was no substantial violation of the assumption of no multicollinearity. We conducted five separate regression models. In each model, we set the response variable to one of the five "ethical beliefs" dependent variables.

Regression 1-Item 14: It is acceptable for companies to implement unethical tax policies if this is the only way to keep them competitive.

Table 3. Regression Results: Item 14: It is Acceptable for Companies to Implement Unethical Tax Policies if This is the Only Way to Keep Them Competitive

\begin{tabular}{|l|c|c|c|c|c|}
\hline & Estimate & SE & Wald & p-value & 95\% CI \\
\hline Government & -0.24 & 0.07 & 11.7 & 0.0006 & $(-0.38,-0.10)$ \\
\hline Tax Rate/System & 0.01 & 0.07 & 0.03 & 0.8518 & $(-0.12,0.14)$ \\
\hline Tax Legislation/Collection & -0.10 & 0.07 & 2.05 & 0.1519 & $(-0.25,0.04)$ \\
\hline Tax Use/Enforcement & -0.22 & 0.07 & 10.20 & 0.0014 & $(-0.36,-0.08)$ \\
\hline
\end{tabular}

Source: Authors' elaboration

Interpretations: The model reveals a statistically significant relationship between (Government, Tax Use/Enforcement) and Item 14. More specifically:

$>$ For every one-unit increase in the Government factor, there is a .24 decrease in Item 14.

$>$ For every one-unit increase in the Tax Use/Enforcement factor, there is a .22 decrease in Item 14.

Regression 2 - Item 15: Tax avoidance is ethical if tax levels are too high.

Table 4. Regression Results: Item 15: Tax Avoidance is Ethical if Tax Levels are too High

\begin{tabular}{|l|c|c|c|c|c|}
\hline & Estimate & SE & Wald & p-value & 95\% CI \\
\hline Government & -0.30 & 0.07 & 17.71 & 0.0001 & $(-0.45,-0.16)$ \\
\hline Tax Rate/System & 0.18 & 0.07 & 7.16 & 0.0074 & $(0.04,0.32)$ \\
\hline Tax Legislation/Collection & 0.07 & 0.07 & 0.89 & 0.3456 & $(-0.08,0.22)$ \\
\hline Tax Use/Enforcement & -0.28 & 0.07 & 16.37 & 0.0001 & $(-0.43,-0.14)$ \\
\hline
\end{tabular}

Source: Authors' elaboration

Interpretations: The model reveals a statistically significant relationship between (Government, Tax Rate/System, Tax Use/Enforcement) and Item 15. More specifically: 
For every one-unit increase in the Government factor, there is a 0.3 decrease in Item 15.

$>$ For every one-unit increase in the Tax/Rate/System factor, there is a .18 increase in Item 15 .

$>$ For every one-unit increase in the Tax Use/Enforcement factor, there is a .28 decrease in Item 15.

Regression 3 - Item 16: Tax avoidance is ethical if everyone does it.

Table 5. Regression Results: Item 16: Tax Avoidance is Ethical if Everyone Does It

\begin{tabular}{|l|c|c|c|c|c|}
\hline & Estimate & SE & Wald & p-value & 95\% CI \\
\hline Government & -0.03 & 0.07 & 0.17 & 0.6767 & $(-0.17,0.11)$ \\
\hline Tax Rate/System & -0.07 & 0.07 & 1.24 & 0.2648 & $(-0.21,0.06)$ \\
\hline Tax Legislation/Collection & -0.08 & 0.07 & 1.10 & 0.2935 & $(-0.23,0.07)$ \\
\hline Tax Use/Enforcement & 0.06 & 0.07 & 0.76 & 0.3829 & $(-0.08,0.20)$ \\
\hline
\end{tabular}

Source: Authors' elaboration

Interpretations: The model reveals no statistically significant relationships between the factors and Item 16 .

Regression 4 - Item 17: Fiscal evasion is morally wrong and unethical in any form and size.

Table 6. Regression Results: Item 17: Fiscal Evasion is Morally Wrong and Unethical in any Form and Size

\begin{tabular}{|l|c|c|c|c|c|}
\hline & Estimate & SE & Wald & p-value & 95\% CI \\
\hline Government & 0.05 & 0.07 & 0.57 & 0.4513 & $(-0.09,0.19)$ \\
\hline Tax Rate/System & -0.08 & 0.07 & 1.49 & 0.2229 & $(-0.21,0.05)$ \\
\hline Tax Legislation/Collection & -0.04 & 0.07 & 0.30 & 0.5827 & $(-0.19,0.11)$ \\
\hline Tax Use/Enforcement & -0.18 & 0.07 & 7.20 & 0.0073 & $(-0.32,-0.04)$ \\
\hline
\end{tabular}

Source: Authors' elaboration

Interpretations: The model reveals a statistically significant relationship between Tax Use/Enforcement and Item 17. More specifically:

For every one-unit increase in the Tax Use/Enforcement factor, there is a .18 decrease in Item 17.

Regression 5 - Item 18: Tax evasion is ethical even if the tax level is not very high because the government has no right to take as much as it takes from me.

Table 7. Regression Results: Item 18: Tax Evasion is Ethical Even if the Tax Level is not very High because the Government Has no Right to Take as Much as It Takes from the Author

\begin{tabular}{|l|c|c|c|c|c|}
\hline & Estimate & SE & Wald & p-value & 95\% CI \\
\hline Government & -0.54 & 0.07 & 46.14 & 0.0001 & $(-0.70,-0.38)$ \\
\hline Tax Rate/System & 0.23 & 0.07 & 9.95 & 0.0016 & $(0.09,0.37)$ \\
\hline Tax Legislation/Collection & -0.06 & 0.07 & 0.73 & 0.3932 & $(-0.22,0.09)$ \\
\hline Tax Use/Enforcement & -0.34 & 0.07 & 20.55 & 0.0001 & $(-0.50,-0.19)$ \\
\hline
\end{tabular}

Source: Authors' elaboration

Interpretations: The model reveals a statistically significant relationship between (Government, Tax Rate/System, Tax Use/Enforcement) and Item 18. More specifically:

For every one-unit increase in the Government factor, there is a .54 decrease in Item 18.

$>$ For every one-unit increase in the Tax Rate/System factor, there is a .23 increase in Item 18.

$>$ For every one-unit increase in the Tax Use/Enforcement factor, there is a .34 decrease in Item 18.

3.2.2 Overall Interpretations. The phenomenon of tax evasion is pervasive in Albania, as data from reports of governmental and international organizations have shown over the years. The attitude of individuals in favor of committing evasion or tax avoidance is not explicitly related to different types of entities that can do it (those who own a business). However, the spread of perceptions in its favor is also higher among people unable to evade (for example, public or private sector employees). Respondents' views on tax avoidance and evasion have shown a tendency towards a rise in tax evasion potential. This trend is observed across various employment types, genders, ages, education levels, and residential areas. This pattern may have been influenced by the repeated use of amnesty and the common perception that the payment of taxes must be balanced by appropriate facilities and the correctness and transparent behavior of the government that administer the tax collections and usage.

The are several patterns observed from the preceding regression results.

The more an individual tends to perceive the government's role in the tax system positively, the more they tend to believe tax avoidance and evasion are unethical (by an individual or a company). 
$>$ Overall, even if an individual believes that the tax system and contribution amounts are fair, they tend to believe that tax avoidance is ethical if the tax rates get too high. For them, tax evasion is ethical because the government takes too much money from them in taxes.

$>$ Overall, individuals who believe that tax use and enforcement are essential factors that affect tax avoidance and evasion less likely to feel that tax avoidance and tax evasion are unethical.

$>$ People do not feel it is right to avoid or evade taxes just because everyone does it. No factor influenced this outcome overall.

\section{Conclusions and Recommendations}

This study aimed to determine how individual Albanian taxpayers feel about the tax system and the factors influencing tax avoidance and evasion. Tax avoidance and evasion practices are widespread, have always been, and will undoubtedly be the same in the future. We have identified and analyzed four potential factors influencing tax avoidance and tax evasion during our research study: government policies acceptance: tax rates and structure, tax legislation and collection, and tax use/enforcement. Torgler (2007) founded that procedural fairness had a leading role regarding the taxpayers' satisfaction level with the government. Institutional positive actions will cause a reciprocation in taxpayers' behavior. We found in our study that Factor 1 consistently demonstrates a significant inverse relationship with whether an individual believes that tax avoidance and evasion are ethical. The more an individual believes that the government is playing a positive role in tax levying, collection, and enforcement, the less likely they believe that tax avoidance and evasion are ethical. These beliefs of positive institutional behavior positively influence the level of tax compliance for the taxpayers. This finding supports our second hypothesis (H2).

We further found that even if an individual felt that the tax rates and progressive tax system were fair and appropriate, as indicated in Factor 2, they believed that tax avoidance might be ethical if the rates become too high. The results confirm other studies. The level of tax enforcement is more affected by the confidence of taxpayers in the government, particularly against the tax system. If taxes charged and public services offered by the government are deemed to be fair to the taxpayer, taxpayers will want to comply with tax legislation, and this has a positive impact on tax compliance (Feld and Frey, 2002; Torgler et al., 2008). Furthermore, even when an individual was agreeable with the tax rate and system, they still believed that the government was taking too much, and that tax evasion may be ethical. One possible explanation of this interesting finding may be that individuals can justify the tax rates by the benefits received up to a certain point. However, if rates become too high (or they overthink tax is taken from them), evasion or avoidance may be ethical regardless of the fairness of the progressive system. This finding seems to lead to an inconclusive stance on our third hypothesis (H3).

Finally, we found that individuals felt that misuse of taxes and lack of enforcement affect tax avoidance and evasion as indicted in Factor 3. The findings of this research confirm the results of previous studies by Turner (2005), Saad (2009), Kogler et al. (2013), and Razak and Adafula (2013), which have shown that tax perception can influence tax enforcement and that taxpayers' perception of government role will affect the citizens' intention to comply. Empirical data shows that a taxpayer who has a positive view of the government would be more likely to cooperate than a taxpayer who has a wrong perception of the government. Tax officials should also take a range of steps to allow taxpayers to value the administration role and establish a rational tax structure. Based on the results of the analysis, some of the recommendations addressed to tax policymakers are:

$>$ Design and implementation of a tax system as transparent and straightforward as possible for individual taxpayers.

$>$ The taxpayer's mentality toward the government is undoubtedly one of the most critical factors influencing tax avoidance and evasion. From the taxpayer's standpoint, if the government manages the taxpayer's money correctly, most taxpayers felt optimistic about paying their taxes (Oberholzer, 2008a). The taxpayer would be even more committed to compliance with tax laws as the government spends the taxpayer's money on improving the taxpayer's life and looking after him, such as making him feel safe or maintaining hospitals and schools in good working order.

$>$ It is vital to improving the tax collection system and better manage the funds raised by government bodies as this boosts taxpayers' confidence and boosts tax compliance to levels and higher in the future.

Since tax evasion is such a complicated and systemic phenomenon, a single approach would not suffice to minimize it to appropriate levels. To enhance tax collection and improve their administration, a structured package of tools is needed that, on the one hand, discourages taxpayers from evading taxes while, on the other hand, simplifies the administration's job. 
4.1 Limitations of the Study and Future Research. We plan to extend this study in several ways in the future. First, we would like to create a new survey that more fully captures Albania's tax culture's beliefs. Because the questions around tax culture loaded too low in our factor analysis, we believe that a more focused survey on specific cultural characteristics surrounding tax culture would be appropriate. Next, we would like to investigate further the ethical beliefs regarding tax avoidance and evasion, specifically from the viewpoint of business owners. Because our questions regarding unfair business competition and profit-making had to be eliminated, we could not evaluate our first hypothesis (H1). We would also like to analyze the effects of demographic characteristics on individuals' ethical beliefs surrounding tax avoidance and evasion.

Author Contributions. Conceptualization Oltiana Muharremi, Michael J. Salé, Meleq Hoxhaj; data curation, Meleq Hoxhaj; formal analysis, Michael J. Salé, Oltiana Muharremi; investigation, Michael J. Salé; methodology, Michael J. Salé; project administration, Oltiana Muharremi, Meleq Hoxhaj; resources, Meleq Hoxhaj; software, Michael J. Salé; supervision, Oltiana Muharremi, Michael J. Salé; validation, Michael J. Salé, Oltiana Muharremi; visualization, Michael J. Salé; writing - original draft, Oltiana Muharremi, Michael J. Salé.

Funding. There is no funding for this research.

\section{References}

1. Abdu, M., Jibir, J. \& Muhammad, T. (2021). Analysis of Tax Compliance in Sub-Saharan Africa: Evidence from Firm-Level Study. Econometric Research in Finance, 5(2), 119-142. https://doi.org/10.2478/erfin$2020-0007$.

2. Adebisi, J.F. \& Gbegi, D.O. (2013). Effect of Tax Avoidance and Tax Evasion on Personal Income Tax Administration in Nigeria. American Journal of Humanities and Social Science, 1(3), 125-134. https://doi.org/10.11634/232907811604328.

3. Alm, J. \& Torgler, B. (2011). Do Ethics Matter? Tax Compliance and Morality. Journal of Business Ethics, 101, 635-651. https://doi.org/10/1007/s10551-011-0761-9

4. Alm, J., Martinez-Vazquez, J. \& McClellan, C. (2016). Corruption and firm tax evasion. Journal of Economic Behaviour \& Organization, 124, 146-163. DOI:10.1016/j.jebo.2015.10.006.

5. Andoni, M., Osmani M. \& Kambo, A. (2017). Assessing Determinants of Tax Evasion in Albania-A Multinomial Econometric Approach, European Journal of Business, Economics and Accountancy, 5(3), 9-21. Available at: http://www.idpublications.org/wp-content/uploads/2017/04/Full-Paper-ASSESSINGDETERMINANTS-OF-TAX-EVASION-IN-ALBANIA.pdf.

6. Andrighetto, G., Zhang, N., Ottone, S., Ponzano, F., D'Attoma, J. \& Steinmo, S. (2016). Are Some Countries More Honest than Others? Evidence from a Tax Compliance Experiment in Sweden and Italy. Front. Psychol, 7, 472. https://doi.org/10.3389/fpsyg.2016.00472.

7. Bosco, L. \& Mittone, L. (1997). Tax evasion and moral constraints: some experimental evidence. Kyklos, 50, 297-324. https://doi.org/10.1111/1467-6435.00018.

8. Camerer, F.C., Ho, T-H. \& Chong, J-H. (2004). A Cognitive Hierarchy Model of Games. The Quarterly Journal of Economics, 119(3), 861-898. https://doi.org/10.1162/0033553041502225.

9. Chen, H., Schneider, F. \& Sun, Q. (2019). Measuring the size of the shadow economy in 30 provinces of China over 1995-2016: The MIMIC approach. Pacific Economic Review, 25(3), 307-453. https://doi.org/10.1111/1468-0106.12313

10.Chiarini, B., Marzano, E. \& Schneider, F. (2013). Tax Rates and tax evasion: an empirical analysis of the long run aspects in Italy. European Journal of Law and Economics, 35, 273-293. https://doi.org/10.1007/s10657-011-9247-6.

11.D' Attoma, J., Volintiru, C. \& Steinmo, S. (2017). Willing to share? Tax compliance and gender in Europe and America. Research and Politics, 4(2), 1-10. https:doi.org/10.1177/2053168017707151.

12.Feld, L. \& Frey, B. (2002). Trust Breeds Trust: How Taxpayers are Treated. Economics of Governance, 3, 87-99. http://dx.doi.org/10.1007/s101010100032.

13.Feige, E. (1990). Defining and Estimating Underground and Informal Economies: The New Institutional Economics Approach. World Development, 18(7), 989-1002. https://doi.org/10.1016/0305750X(90)90081-8.

14.Fischer, C.M., Wartick, M. \& Mark, M. (1992). Detection probability and taxpayer compliance: A review of the literature. Journal of Accounting Literature, 11, 1-46. Available at: https://search.proquest.com/openview/181022c45a0e3880d623df038bc7e494/1?pqorigsite $=$ gscholar $\& \mathrm{cbl}=31366$. 
15.Fisman, R., \& Wei, S. (2004). Tax Rates and Tax Evasion: Evidence from "Missing Import" in China. Journal of Political Economy, 112(2), 471-500. DOI:10.1086/381476.

16.Gashi, M. \& Kukaj, H. (2016). The Effect of Tax Rates on Fiscal Evasion and Avoidance. European Journal of Sustainable Development, 5(1), 31-38. https://doi.org/10.14207/ejsd.2016.v5n1p31.

17.Hofmann, E., Hoelzl, E., \& Kirchler, E. (2008). Preconditions of Voluntary Tax Compliance: knowledge and evaluation of Taxation, Norms, Fairness, and Motivation to Cooperate, Zeitschrift für Psychologie/J Psychol, 216(4), 209-217. https://doi.org/10.1027/0044-3409.216.4.209.

18.Kasipillai, J., Aripin, N., \& Amran, N. (2013). The Influence of Education on Tax Avoidance and Tax Evasion. eJournal of Tax Research, [online] 1(2). Available at: http://www.austlii.edu.au/au/journals/eJTR/2003/7.html.

19. Kleven, H., Knudsen, M., Kreiner, C., Pedersen, S., \& Saez, E. (2011). Unwilling or Unable to Cheat? Evidence from a Tax Audit Experiment in Denmark. Econometrica, 79(3), 651-692. Available at: http://www.jstor.org/stable/41237767.

20.Kirchler, E. (2007). The economic psychology of tax behaviour. Cambridge University Press. https://doi.org/10.1017/CBO9780511628238.

21.Kogler, C., Batrancea, L., Nichita, A., Pantya, J., Belianin, A., and Kirchler, E. (2013). Trust and power as determinants of tax compliance: Testing the assumptions of the slippery slope framework in Austria, Hungary, Romania, and Russia. Journal of Economic Psychology, 34, 169-180. http://dx.doi.org/10.1016/j.joep.2012.09.010.

22.Kogler, C., \& Kirchler, E. (2019). Taxpayers' Subjective Concepts of Taxes, Tax Evasion, and Tax Avoidance. Ethics and Taxation. https://doi.org/10.1007/978-981-15-0089-3 8 .

23.Mamuti, A., \& McGee, R. (2016). Tax Evasion as a Crime: A Survey of Perception in Kosovo. http://dx.doi.org/10.2139/ssrn.2987724.

24.McGee, W. (2006). Three Views on the Ethics of Tax Evasion. Journal of Business Ethics, 67, 15-35. https://doi.org/10/1007/s10551-006-9002-z.

25.McGee, R.W. (2014). The Ethics of Tax Evasion: A Case Study of Brazil. In B. Christiansen (Ed.), Handbook of Research on Economic Growth and Technological Change in Latin America, IGI Global, Hershey, PA, USA: IGI Global, 374-393. https://doi.org/10.4018/978-1-4666-6224-7.ch022.

26.Muceku, H., \& Balliu, T. (2017). The Albanian Taxpayers' Perception of the Current Tax System and Its Impact on Informal Economy, Tax Evasion and Tax Avoidance. Mediterranean Journal of Social Sciences, 8(1), 470. Available at: https://www.richtmann.org/journal/index.php/mjss/article/view/9719.

27.Muharremi, O., Madani, F., \& Pelari, E. (2014). Tax Evasion and Set Backs of the Shadow Economy in Albania. Mediterranean Journal of Social Sciences, 5(13), 398-408. Available at: https://www.richtmann.org/journal/index.php/mjss/article/view/3601.

28. Oberholzer, R. (2008). Attitudes of South African taxpayers towards taxation: a pilot study. UPSpace Collection, 44-69. Available at: http://visar.csustan.edu/aaba/Oberholzer2008.pdf.

29. OECD (2004). The informal economy in Albania. Analysis and policy recommendations. Central European Initiative (CEI). Available at: https://www.researchgate.net/profile/Ricardo-Pinto39/publication/282733678_The_Informal_Economy_in_Albania_analysis_and_policy_recommendations/ links/561a91d408ae78721f9f8add/The-Informal-Economy-in-Albania-analysis-and-policyrecommendations.pdf.

30.Onu, D., \& Oats, L. (2016). Paying tax is part of life: Social norms and social influence in tax communications. Journal of Economic Behavior \& Organization, 124, 29-42. https://doi.org/10.1016/i.jebo.2015.11.017.

31.Payne, J.E., \& Saunoris, J.W. (2020). Corruption and Firm Tax Evasion in Transition Economies: Results from Censored Quantile Instrumental Variables Estimation. Atlantic Economic Journal, 48(2), 195-206. https://doi.org/10/1007/s11293-020-09666-2.

32.Razak, A.A., \& Adafula, C.J. (2013). Evaluating taxpayers' attitude and its influence on tax compliance decisions in Tamale, Ghana. Journal of Accounting and Taxation, 5(3), 48-57. http://dx.doi.org/10.5897/JAT2013.0120.

33.Santoro, A. (2010). L'evasione fiscale. Quanto, come e perché [Tax evasion, how much, how and why?], pp. 18-29.

34.Sanyal, A., Gang, I. N., \& Goswami, O. (2000). Corruption, tax evasion, and Laffer Curve. Public Choice, 105(1-2), 61-78. https://doi.org/10.1023/A:1005105822911.

35.Slemrod, J. (2007). Cheating ourselves: the economics of tax evasion. Journal of Economic Perspectives, 21(1), 25-48. https://doi.org/10.1257/jep.21.1.25. 
36.Tanto, V. (2021). Tax Avoidance in Albania. European Journal of Economics and Business Studies, 6(3), 124-136. Available at: http://journals.euser.org/index.php/ejes/article/view/4926.

37.Tarekegn, M. (2016). Taxpayers' Perception on the Seriousness of Tax Evasion in Dessie Town Administration, Ethiopia. Research Journal of Finance and Accounting (Online), 7(19), 93. Available at: https://core.ac.uk/download/pdf/234631842.pdf.

38.Torgler, B., \& Schaltegger, C.A. (2006). Tax morale: a survey with a special focus on Switzerland. Swiss. Journal of Economics and Statistics, 142(3), 395-425. Available at: https://scholar.google.com/scholar_lookup?title=Tax\%20Morale\%3A\%20A\%20Survey\%20with\%20a\%2 0Special\%20Focus $\% 20$ on $\% 20$ Switzerland $\&$ journal=Swiss $\% 20 J$ ournal $\% 20$ of $\% 20$ Economics $\% 20$ and $\% 20$ Statistics\&volume $=142 \&$ issue $=3 \&$ pages $=395$ 425\&publication_year=2006\&author=Torgler\%2CB\&author=Schaltegger\%2CC\%20A.

39.Torgler, B. (2007). Tax Compliance and Tax Morale: A Theoretical and Empirical Analysis, Cheltenham, UK: Edward Elgar, 2007. https://doi.org/10.4337/9781847207203.

40.Torgler, B., Demir, I.C., Macintyre, A., \& Schaffner, M. (2008). Causes and Consequences of Tax Morale: An Empirical Investigation. Economic Analysis and Policy, 38(2), 313-339. http://dx.doi.org/10.1016/S0313-5926(08)50023-3.

41.Turner, J.C. (2005). Explaining the nature of power: A three-process theory. European Journal of Social Psychology, 35(1), 1-22. http://dx.doi.org/10.1002/ejsp.244.

42.Wenzel, M. (2004). An analysis of norm processes in tax compliance. Journal of Economic Psychology, 25(2), 213-228. https://doi.org/10.1016/S0167-4870(02)00168-X.

43.World Bank Report (2013). Enterprise Survey, Albania Country Profile. Available at: http://documents1.worldbank.org/curated/en/337391468003295834/pdf/922900WP0Box380PUBLIC00A $\underline{\text { lbania02013.pdf. }}$ 


\section{Appendix A. Survey Questions/Items}

Item 1: Tax legislation is simple to understand and apply.

Item 2: The personal income tax rate is appropriate.

Item 3: The social and health insurance contribution rate is appropriate.

Item 4: The tax system of our country is fair to everyone.

Item 5: The progressive personal income tax system is fair.

Item 6: I am confident that the government is doing a good job in collecting taxes.

Item 7: The government uses properly the taxes and fees collected.

Item 8: Individuals have information on how the taxes collected from them by the government are used.

Item 9: The government is interested in having the opinion of their citizens before making legal changes.

Item 10: The current fiscal system favors high-income individuals rather than low- and middle-income employees.

Item 11: I believe the government is fighting and punishing people who evade taxes and commit tax evasion.

Item 12: The consequences of catching for tax evasion (measures, penalties, fines) are not very serious.

Item 13: There is a general culture in Albania regarding tax avoidance and tax evasion.

Item 14: It is acceptable for companies to implement unethical tax policies if this is the only way to keep them competitive.

Item 15: Tax avoidance is ethical if tax levels are too high.

Item 16: Tax avoidance is ethical if everyone does it.

Item 17: Fiscal evasion is morally wrong and unethical in any form and size.

Item 18: Tax evasion is ethical even if the tax level is not very high because the government has no right to take as much as it takes from me.

Item 19: The desire to achieve significant profits in a short time encourages evasion.

Item 20: Continuous changes in tax legislation and the level of taxes encourage tax avoidance and evasion.

Item 21: A high level of corruption from the tax administration encourages tax avoidance and evasion.

Item 22: The ability of the tax administration to control and collect taxes and levies from individuals and businesses influence tax compliance.

Item 23: A lack of transparency regarding fiscal changes and reforms encourages tax avoidance and evasion. Item 24: Unfair business competition influences tax avoidance and evasion.

Item 25: Frequent and increasing changes of the tax base encourage tax avoidance and evasion.

Item 26: Non-severe punitive measures for violators of the law encourages tax avoidance and evasion.

Item 27: Misuse of revenues collected by the government influences tax avoidance and evasion.

Item 28: The lack of a proper tax culture influences tax avoidance and evasion.

\section{Appendix B. Frequency table of survey respondent demographic characteristics}

\begin{tabular}{|c|c|c|c|}
\hline Demographic Attribute & Requirements/Sample Frame & \multicolumn{2}{|c|}{ Frequencies } \\
\hline Age & 18 year of age or older & $\begin{array}{c}18-30 \\
31-40 \\
41-50 \\
51-60 \\
61+\end{array}$ & $\begin{array}{c}216 \\
113 \\
38 \\
9 \\
11\end{array}$ \\
\hline Gender & Male and female (identified as) & $\begin{array}{c}\text { Male } \\
\text { Female }\end{array}$ & $\begin{array}{l}179 \\
208\end{array}$ \\
\hline Marital Status & Single, married, divorced, and widowed & $\begin{array}{c}\text { Single } \\
\text { Married } \\
\text { Divorced } \\
\text { Widowed } \\
\end{array}$ & $\begin{array}{c}200 \\
174 \\
9 \\
4\end{array}$ \\
\hline Education Level & $\begin{array}{c}\text { Primary school, high school, college } \\
\text { graduate, and post-graduate (highest level } \\
\text { completed) }\end{array}$ & $\begin{array}{l}\text { Primary School } \\
\text { High School } \\
\text { College Graduate } \\
\text { Post-Graduate }\end{array}$ & $\begin{array}{c}14 \\
58 \\
216 \\
99\end{array}$ \\
\hline Residential Area & Urban and rural & $\begin{array}{l}\text { Urban } \\
\text { Rural } \\
\end{array}$ & $\begin{array}{c}306 \\
81\end{array}$ \\
\hline Employment Status & $\begin{array}{l}\text { Unemployed, student, private employee, } \\
\text { public employee, self-employed, and retired }\end{array}$ & $\begin{array}{c}\text { Unemployed } \\
\text { Student } \\
\text { Private Employee } \\
\text { Public Employee } \\
\text { Self-Employed } \\
\text { Retired }\end{array}$ & $\begin{array}{c}44 \\
64 \\
151 \\
78 \\
47 \\
3\end{array}$ \\
\hline
\end{tabular}

Source: Authors' elaboration 


\section{Appendix C. Bar charts of the distribution of demographic characteristics of survey respondents}

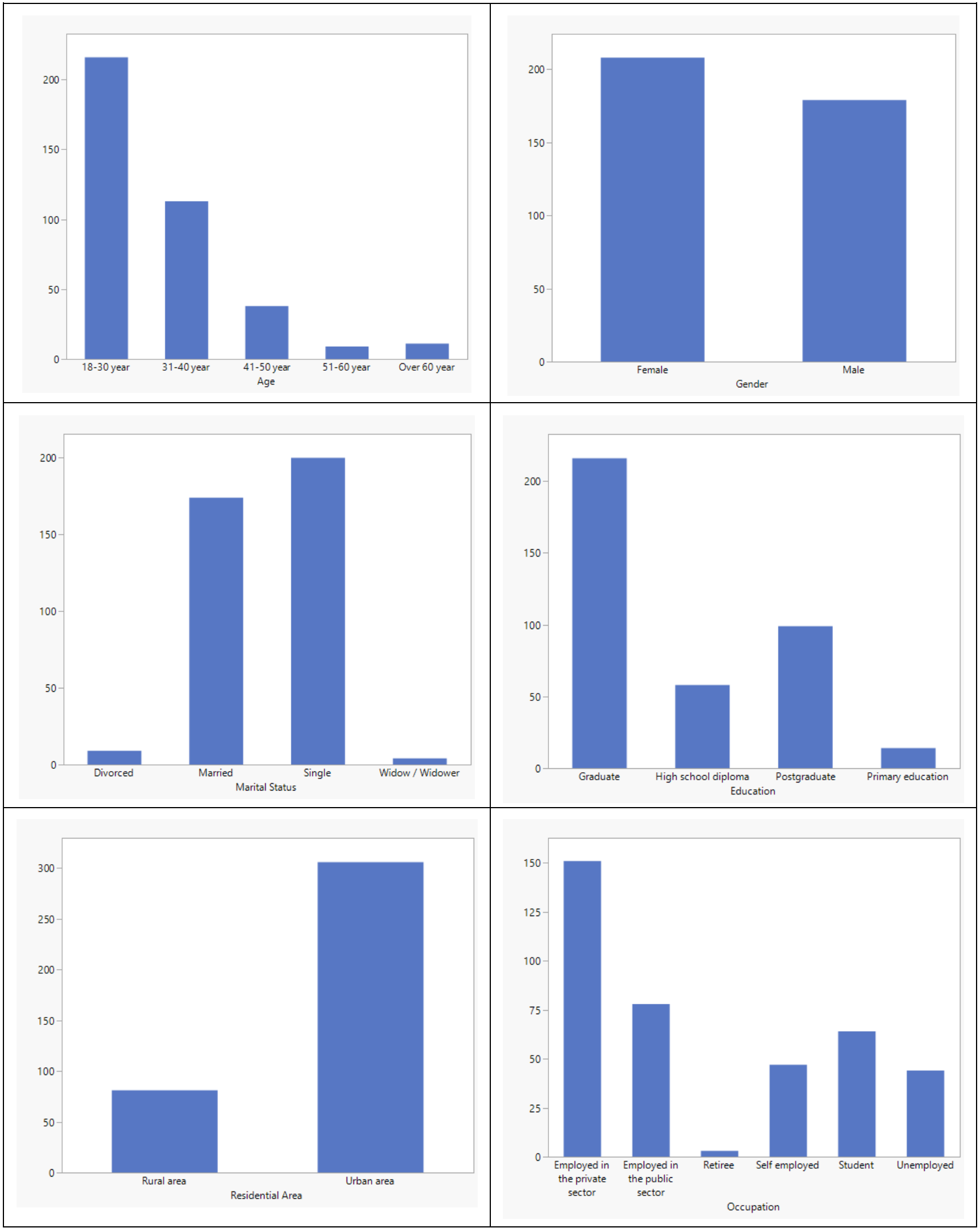

Source: Authors' elaboration 